\title{
Stoichiometry of the Glial Glutamate Transporter GLT-1 Expressed Inducibly in a Chinese Hamster Ovary Cell Line Selected for Low Endogenous $\mathrm{Na}^{+}$-Dependent Glutamate Uptake
}

\author{
Line M. Levy, ${ }^{1}$ Orpheus Warr, ${ }^{2}$ and David Attwell ${ }^{2}$ \\ ${ }^{1}$ Department of Anatomy, University of Oslo, Blindern, N-0317 Oslo, Norway, and ${ }^{2}$ Department of Physiology, University \\ College London, London, WC1E 6BT, United Kingdom
}

Glutamate transport across the plasma membrane of neurons and glia is powered by the transmembrane electrochemical gradients for sodium, potassium, and $\mathrm{pH}$, but there is controversy over the number of $\mathrm{Na}^{+}$cotransported with glutamate. The stoichiometry of glutamate transporters is important because it determines a lower limit to the extracellular glutamate concentration, [glu] , in both normal and pathological conditions. We used whole-cell clamping to study the stoichiometry of the glial transporter GLT-1, the most abundant glutamate transporter in the brain, expressed under control of the Tet-On system in a Chinese hamster ovary $(\mathrm{CHO})$ cell line selected for low endogenous glutamate transport. After the induction of GLT-1 expression with doxycycline, glutamate evoked a $\mathrm{Na}^{+}$dependent inward current with the voltage dependence and pharmacology of GLT-1 and acidified the cell cytoplasm. Raising $\left[\mathrm{K}^{+}\right]_{\mathrm{o}}$ around cells clamped with electrodes containing so- dium and glutamate evoked an outward reversed uptake current. These responses were reduced by the specific GLT-1 blocker dihydrokainate (DHK). DHK evoked an outward current with $\mathrm{NO}_{3}{ }^{-}$, but not with $\mathrm{Cl}^{-}$, as the main intracellular anion, suggesting that the anion conductance of the transporter is active even without external glutamate but generates little current in the absence of highly permeable anions like $\mathrm{NO}_{3}{ }^{-}$. Measuring the reversal potential of the transporter current in various ionic conditions suggested that the transport of one glutamate anion is coupled to the cotransport of three $\mathrm{Na}^{+}$and one $\mathrm{H}^{+}$and to the countertransport of one $\mathrm{K}^{+}$. This suggests that in ischemia, when $\left[\mathrm{K}^{+}\right]_{\mathrm{o}}$ rises to $60 \mathrm{~mm}$, the reversal of glutamate transporters will raise $[\mathrm{glu}]_{0}$ to $>50 \mu \mathrm{M}$.

Key words: glutamate; uptake; inducible expression; $\mathrm{CHO}$ cell line; GLT-1; transport
The extent to which glutamate uptake can lower the extracellular glutamate concentration, [glu $]_{\mathrm{o}}$, in the CNS is determined by the ionic stoichiometry of the uptake process (Attwell et al., 1993). Radiotracing and whole-cell clamp experiments suggested that the entry of each glutamate anion into the cell is accompanied by the cotransport of two $\mathrm{Na}^{+}$ions (Baetge et al., 1979; Stallcup et al., 1979; Erecinska et al., 1983) and the countertransport of one $\mathrm{K}^{+}$ion (Kanner and Sharon, 1978; Barbour et al., 1988; Amato et al., 1994a). In addition, glutamate transporters generate $\mathrm{pH}$ changes, acid inside and alkaline outside the cell (Erecinska et al., 1983; Bouvier et al., 1992; Billups et al., 1996). On the basis of anion substitution experiments these $\mathrm{pH}$ changes were attributed by Bouvier et al. (1992) to the countertransport of an $\mathrm{OH}^{-}$out of the cell, but with the discovery of an anion conductance in the GLAST transporter they studied, their data have been reinterpreted as being equally compatible with cotransport of an $\mathrm{H}^{+}$ into the cell (Billups et al., 1996; Eliasof and Jahr, 1996). The observation that the neuronal EAAT3 transporter can transport both anionic and neutral (i.e., protonated) cysteine led Zerangue and Kavanaugh (1996a) to suggest that energy is gained from the $\mathrm{pH}$ gradient by cotransport of an $\mathrm{H}^{+}$(presumably anionic cys-

\footnotetext{
Received May 21, 1998; revised Aug. 10, 1998; accepted Sept. 14, 1998.

This work was supported by the European Community (CT 95-871), the Wellcome Trust, the Medical Research Council, and the Langfeldt and Nansen foundations. We thank Rick Ash for providing the cell line in which GLT-1 was expressed. We also thank Niels Christian Danbolt, Alasdair Gibb, Mark Farrant, and Angus Silver for comments on this manuscript.

Correspondence should be addressed to Dr. Line M. Levy, Department of Anatomy, University of Oslo, P.O. Box 1105, Blindern, N-0317 Oslo, Norway. Copyright (C) 1998 Society for Neuroscience 0270-6474/98/189620-09\$05.00/0
}

teine is transported with a cotransported $\mathrm{H}^{+}$, and neutral cysteine is transported with the $\mathrm{H}^{+}$attached to the cysteine).

Two recent studies on the EAAC1/EAAT3 transporter have given contradictory results for the number of $\mathrm{Na}^{+}$, and hence the charge, cotransported. Using measurements of radioactive $\mathrm{Na}^{+}$ influx, $\mathrm{pH}$, and membrane current, Kanai et al. (1995) concluded that two $\mathrm{Na}^{+}$and one net charge moved per glutamate entering the cell on EAAC1. By contrast, Zerangue and Kavanaugh (1996b), who studied the reversal potential of the homologous transporter EAAT3, concluded that three $\mathrm{Na}^{+}$and two net charges were transported per glutamate.

A detailed analysis of the stoichiometry of the glial GLT-1/ EAAT2 transporter has not yet been performed and is of interest because this is the most abundant glutamate transporter in the brain (Haugeto et al., 1996). Although it is known that this transporter cotransports $\mathrm{Na}^{+}$and countertransports $\mathrm{K}^{+}$(Kanner and Sharon, 1978; Pines et al., 1992), the number of ions moving has not been examined rigorously, and it is uncertain whether $\mathrm{H}^{+}$ is involved in powering this transporter. We recently have developed a cell line in which GLT-1 is expressed under the control of the Tet-On system (so expression is turned on by adding the antibiotic doxycycline), and there is essentially no contamination from other $\mathrm{Na}^{+}$-dependent transporters or glutamate-gated currents (Levy et al., 1998). We have used whole-cell clamping to characterize the properties of GLT-1 in this cell line. Using the nontransported analog of glutamate, dihydrokainate (DHK), which is a specific blocker of GLT-1, we show that the reversal potential of the transporter is consistent with glutamate transport 
being accompanied by the cotransport of three $\mathrm{Na}^{+}$and one $\mathrm{H}^{+}$ and the countertransport of one $\mathrm{K}^{+}$.

\section{MATERIALS AND METHODS}

All experiments were performed at room temperature, $21-25^{\circ} \mathrm{C}$. Before experiments the cells were cultured at $37^{\circ} \mathrm{C}$ in a humidified $5 \% \mathrm{CO}_{2}$ incubator in DMEM/Ham's F12 culture medium (Life Technologies 21331, Gaithersburg, MD) supplemented with $2.5 \mathrm{~mm}$ glutamine, nonessential amino acids (Life Technologies 11140-035, diluted 1:200), 5\% newborn calf serum, and 5\% horse serum.

Cell line expressing GLT-1. Construction of the cell line GLT-1/Dd-B7 has been described previously (Levy et al., 1998). In brief, the first step (Igo and Ash, 1996) was to select a Chinese hamster ovary (CHO) cell line (Dd-B7) to have essentially no $\mathrm{Na}^{+}$-dependent glutamate transport, by bathing a population of mutagenized cells in tritiated $\mathrm{D}$-aspartate (a glutamate transporter substrate) and storing the cells to allow time for cells that had taken up the D-aspartate to be killed by radiation damage. This process left a cell population enriched in cells lacking transporters. The second step was to cotransfect a resulting clonal cell line with the pTet-On regulator plasmid and with GLT-1 cDNA inserted in the pTet response element plasmid (Resnitzky et al., 1994; Gossen et al., 1995) and select the clonal cell line with the largest increase of D-aspartate uptake induced by doxycycline (which binds to the reverse Tetresponsive transcriptional activator, activating the expression of GLT-1). Doxycycline was found to upregulate tritiated D-aspartate uptake by a factor of 280 (Levy et al., 1998), this maximum upregulation occurring $36-48 \mathrm{hr}$ after doxycycline $(2 \mu \mathrm{g} / \mathrm{ml})$ was added. GLT-1 was extracted from the cell line and from rat cerebral cortex by immunoabsorption (Haugeto et al., 1996) with the use of sheep antibodies to amino acids 492-501 of GLT-1, was separated by SDS-PAGE, and was immunoblotted with rabbit antibodies to GLT-1. The molecular weight of GLT-1 from cerebral cortex was $\sim 70 \mathrm{kDa}$, as reported previously (Lehre et al., 1995), whereas that of GLT-1 from the cell line was $\sim 80 \mathrm{kDa}$. This difference presumably is attributable to different glycosylation, because after deglycosylation with $N$-glycosidase F (Danbolt et al., 1992), the molecular weight of GLT-1 from both sources was the same ( $\sim 60 \mathrm{kDa})$. The reduction in molecular weight is unlikely to be attributable to proteolysis because the deglycosylated proteins were recognized by antibodies (Lehre et al., 1995) to both the N-terminal (amino acids 12-26) and the C-terminal (amino acids 518-536).

Whole-cell clamping. Cells were detached from their culture wells by being washed with a solution containing (in $\mathrm{mM}$ ) $137 \mathrm{NaCl}, 0.7 \mathrm{~K}_{2} \mathrm{HPO}_{4}$,

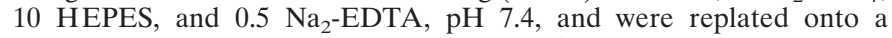
glass-bottomed chamber that had been half-filled with external solution (see below; the divalent ions in this solution allow the cells to adhere to the chamber) on a fixed stage microscope. Electrode resistance was $\sim 2$ $\mathrm{M} \Omega$ when immersed in the external solution and $1 \mathrm{G} \Omega$ in the cellattached mode; the series resistance in whole-cell mode was $\sim 5 \mathrm{M} \Omega$. Series resistance voltage errors were negligible $(<1 \mathrm{mV})$. The cells are approximately spherical after being replated, as described above, so voltage nonuniformity in the cell is also negligible. The membrane potential was corrected for the electrode junction potential.

Solutions. For measuring forward uptake currents, the cells were clamped with electrodes filled with solution containing (in $\mathrm{mM}$ ) $140 \mathrm{KCl}$, $0.5 \mathrm{CaCl}_{2}, 5 \mathrm{Na}_{2}$-EGTA, 10 HEPES, $2 \mathrm{MgCl}_{2}$, and $1 \mathrm{Na}_{2} \mathrm{ATP}$, pH 7.0, in external solution containing (in $\mathrm{mM}$ ) $140 \mathrm{NaCl}, 2.5 \mathrm{KCl}, 10 \mathrm{HEPES}$, $2 \mathrm{MgCl}_{2}, 2.5 \mathrm{CaCl}_{2}, 1 \mathrm{Na}_{2} \mathrm{HPO}_{4}$, and 10 glucose, $\mathrm{pH}$ 7.4. For measuring reversed uptake currents, the pipette solution contained (in $\mathrm{mM}$ ) 10 Na-glutamate, 124 choline-Cl or 124 tetraethylammonium-Cl (similar results were obtained with either), $0.5 \mathrm{CaCl}_{2}, 5$ ( $N$-methyl-Dglucamine $)_{2}$-EGTA, and $10 \mathrm{HEPES}, \mathrm{pH} 7.0$; the external solution contained (in mM) $73.5 \mathrm{NaCl}, 60$ choline-Cl or $60 \mathrm{KCl}, 2 \mathrm{MgCl}_{2}, 2.5 \mathrm{CaCl}_{2}$, $6 \mathrm{BaCl}_{2}$ (to block inward rectifier potassium channels), $10 \mathrm{HEPES}, 10$ glucose, and 0.1 ouabain (to block the $\mathrm{K}^{+}$-evoked $\mathrm{Na} / \mathrm{K}$ pump current). Reversed uptake was evoked by replacing the external choline- $\mathrm{Cl}$ with $\mathrm{KCl}$. For experiments to determine the stoichiometry by measuring the reversal potential of the current blocked by DHK, both the internal and external solutions contained $\mathrm{Na}^{+}, \mathrm{K}^{+}$, and glutamate to allow forward and reversed operation of the transporter (at different voltages); $\mathrm{Cl}^{-}$was omitted from the internal and external solutions to abolish any contribution to the membrane current from the anion channel of the transporter (Wadiche et al., 1995a) although, as discussed later, there is little anion conductance for this transporter when $\mathrm{Cl}^{-}$is the main anion present. The pipette solution contained (in mM) 10 Na-glutamate, 10 Na-gluconate, $122 \mathrm{~K}$-gluconate, $2 \mathrm{Mg}$-(gluconate) ${ }_{2}, 0.5 \mathrm{Ca}$-(gluconate) ${ }_{2}$,
$5 \mathrm{Na}_{2}$-EGTA, and $10 \mathrm{HEPES}$, pH set to 7.0 with $N$-methyl-D-glucamine (NMDG), and the pipette holder was filled with a solution identical except that $\mathrm{Cl}^{-}$replaced gluconate (to enable the operation of the silver chloride electrode of the pipette holder). The control external solution contained (in $\mathrm{mm}$ ) 0.1 Na-glutamate, 100 Na-gluconate, 42.5 K-gluconate, $2 \mathrm{Mg}$-(gluconate) $)_{2}, 2.5 \mathrm{Ca}$-(gluconate) $)_{2}, 1 \mathrm{NaH}_{2} \mathrm{PO}_{4}, 10$ glucose, and 10 HEPES, pH set to 7.4 with NMDG. To examine the effect on the reversal potential of altering the ion gradients, we lowered $[\mathrm{Na}]_{\mathrm{o}}$ to $51 \mathrm{~mm}$ by replacing Na-gluconate with NMDG-gluconate, or $[\mathrm{K}]_{\mathrm{o}}$ was lowered to $10 \mathrm{~mm}$ by replacing K-gluconate with NMDGgluconate, or the $\mathrm{pH}$ was adjusted to 8.0 with $\mathrm{NMDG}$, or [glutamate] was increased from 0.1 to $0.3 \mathrm{~mm}$.

pH measurements. Cells were whole-cell-clamped with the normal pipette solution for forward uptake (see above) but buffered with only 0.5 mM HEPES and with the pH-sensitive fluorescent dye BCECF $(96 \mu \mathrm{M})$ added. External solution was the normal solution for forward uptake, but with the $\mathrm{pH}$ adjusted to 7.7 and, in some experiments, with $1 \mathrm{~mm}$ amiloride added to ensure that the $\mathrm{pH}$ changes seen were not generated by the $\mathrm{Na}^{+} / \mathrm{H}^{+}$exchanger secondary to an uptake-evoked rise of $\left[\mathrm{Na}^{+}\right]_{\mathrm{i}}$ $\left(\mathrm{Na}^{+}-\mathrm{HCO}_{3}{ }^{-}\right.$transporters are inhibited by the absence of $\mathrm{HCO}_{3}{ }^{-}$in our solutions). Fluorescence of the cell was excited at 490 or $440 \mathrm{~nm}$ wavelength (an acid $\mathrm{pH}$ shift decreases fluorescence excited at $490 \mathrm{~nm}$ but has no effect on that at $440 \mathrm{~nm}$ ), and emission at $530 \mathrm{~nm}$ was measured with a photomultiplier. The $\mathrm{pH}$ signal was not calibrated in vivo, but in vitro calibration (Rink et al., 1982) suggests that a typical glutamate-evoked decrease in fluorescence of $2 \%$ (excited at $490 \mathrm{~nm}$ ) corresponds to an acidification of 0.02 units.

Data analysis. All data are presented as mean \pm SEM. To compare experimental data on the transporter reversal potential with theoretical predictions for various stoichiometries (175 of which were considered), we used the average value measured for the reversal potential in the control external solution and the four shifts of reversal potential measured when, in turn, the external concentration of sodium, protons, potassium, and glutamate were altered. For each of these five measurements we computed the absolute value of the difference between the theoretical prediction and the experimental value and then averaged this "error" over the five measurements to crudely assess the relative likelihood that a particular theoretical stoichiometry might be consistent with the data. When this average "error" was $<6 \mathrm{mV}$, which narrowed the search to three possible stoichiometries, a Student's two-tailed $t$ test was used to assess the probability of each measurement being consistent with the theoretical prediction.

\section{RESULTS}

\section{Characteristics of the forward uptake current produced by GLT-1/Dd-B7 cells}

After being cultured in doxycycline for $24-48 \mathrm{hr}$ to induce the expression of GLT-1, glutamate evoked an inward current in whole-cell-clamped GLT-1/Dd-B7 cells. No current was seen in cells that had not been cultured in doxycycline (Levy et al., 1998). The inward current was large at negative potentials and reduced on polarizing to positive potentials, although it was still clearly inward at $+40 \mathrm{mV}$ (Fig. 1). This $I-V$ relation is similar to that reported previously for salamander glial cells (Brew and Attwell, 1987), which express mainly a GLAST homolog, and for the GLT-1 homolog EAAT2 expressed in oocytes (Wadiche et al., 1995a). The lack of an outward current at positive potentials, despite the presence of $\mathrm{Cl}^{-}$in the external solution, is consistent with only a small contribution of an anion conductance to this $I-V$ relation (see below).

Applying increasing doses of glutamate evoked an increasing inward current, the size of which could be fit by a MichaelisMenten dependence on [glu $]_{\mathrm{o}}$ (Fig. 2), with a $K_{\mathrm{m}}$ of $\sim 17 \mu \mathrm{M}$. This value is similar to that found previously for EAAT2 expressed in oocytes (18 $\mu \mathrm{M}$; Arriza et al., 1994) but is significantly lower than that for EAAT2 expressed in COS-7 cells $(97 \mu \mathrm{M}$; Arriza et al., 1994) and higher than that for GLT-1 expressed in HeLa cells (10 $\mu \mathrm{M}$; Pines et al., 1992).

The glutamate-evoked current was abolished when extracellu- 
A

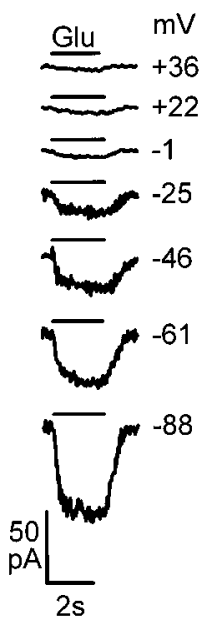

B

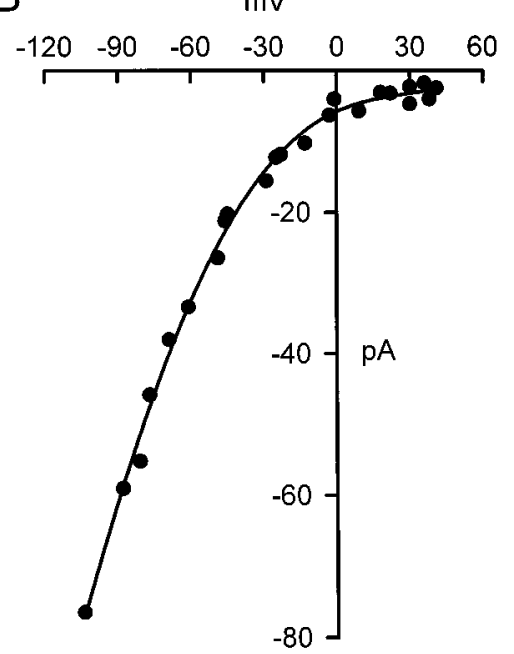

Figure 1. Voltage dependence of glutamate-evoked currents in $\mathrm{CHO}$ cells expressing GLT-1. A, Currents evoked by $100 \mu \mathrm{M}$ glutamate (black bars) in a cell clamped to the potentials shown by each trace. $B$, Peak glutamate-evoked current as a function of voltage for the cell in $A$; similar results were obtained from seven cells.

lar sodium was replaced by choline (Fig. $3 A$, six cells), consistent with glutamate transport requiring $\mathrm{Na}^{+}$cotransport. It was reduced by external DHK (Fig. $3 B$ ), a glutamate analog that binds relatively specifically to GLT-1/EAAT2 but is not transported across the membrane (Pines et al., 1992; Arriza et al., 1994; Wang et al., 1998). On average, in seven cells the response to $200 \mu \mathrm{M}$ glutamate was reduced by $46 \pm 2 \%$ by $200 \mu \mathrm{M}$ DHK. For competitive inhibition, with $K_{\text {glu }}=17 \mu \mathrm{M}$ (see Fig. 2), this is consistent with a Michaelis-Menten constant for DHK binding of $K_{\text {DHK }}=18 \mu \mathrm{M}$, somewhat higher than the $8 \mu \mathrm{M}$ that was found by Wang et al. (1998) for GLT-1 expressed in oocytes but similar to the $23 \mu \mathrm{M}$ found by Arriza et al. (1994) for EAAT2 in COS cells.

DHK evoked no current change itself when $\mathrm{Cl}^{-}$was the main anion present (Fig. 3B, seven cells). However, when the pipette solution contained $\mathrm{NO}_{3}{ }^{-}$as the main anion $\left(130 \mathrm{~mm} \mathrm{KNO}_{3}\right.$ replacing $\mathrm{KCl}$ ), which is much more permeant than $\mathrm{Cl}^{-}$through the anion channel of glutamate transporters (Wadiche et al., 1995a; Billups et al., 1996; Eliasof and Jahr, 1996), DHK evoked a small outward current (Fig. 3C) that was reduced at more positive potentials (Fig. 3D). These data are consistent with the suggestion of Bergles and Jahr (1997) that the anion conductance in GLT-1 is tonically active even in the absence of external glutamate; the efflux of $\mathrm{NO}_{3}{ }^{-}$generates an inward current that is suppressed when DHK binds, presumably because DHK binding shifts the transporter to a state from which the anion channel is not (or is less) activated. This may indicate activation of the anion conductance in the absence of any glutamate bound to the transporter or its activation by the intracellular binding and reversed uptake of glutamate that has not been dialyzed completely out of the cell, as seen previously by Billups et al. (1996). Nevertheless, the anion conductance contributes a negligible current with $\mathrm{Cl}^{-}$ as the main anion present.

\section{Number and density of transporters}

A GLT-1/Dd-B7 cell of $8.5 \mu \mathrm{m}$ average radius (when rounded up; Levy et al., 1998) typically showed an uptake current of $\sim 5 \mathrm{pA}$ at $-60 \mathrm{mV}$ in response to a saturating glutamate concentration. For two charges entering per carrier cycle (as deduced below) and a

cycle time of $100 \mathrm{msec}$ (at $-60 \mathrm{mV}$; Wadiche et al., 1995b), this implies that there are $\sim 1.6 \times 10^{6}$ transporters present in each cell, at a density of $1700 / \mu \mathrm{m}^{2}$.

\section{Reversed uptake mediated by GLT-1}

During brain ischemia the extracellular potassium concentration rises to $60 \mathrm{~mm}$, depolarizing cells and triggering glutamate release by reversed operation of glutamate transporters (Attwell et al., 1993). To examine reversed uptake in GLT-1/Dd-B7 cells, we whole-cell-clamped them to a depolarized or positive potential with a pipette solution containing $10 \mathrm{~mm} \mathrm{Na-glutamate}$ and raised the $[\mathrm{K}]_{\mathrm{o}}$ from 0 to $60 \mathrm{~mm}$. This evoked an outward current component (Fig. 3E) resembling the reversed uptake current characterized by Szatkowski et al. (1990) in retinal glial cells, which was blocked by external glutamate (because when the transporter releases its exported glutamate at the outer membrane surface, external glutamate binds to the glutamate transport site, preventing the transporter from reorienting to the inner membrane surface to pick up more glutamate).

For 5 of the 17 cells studied, like the cell of Figure $3 E$, the $\mathrm{K}^{+}$-evoked current was net outward and was abolished by $200 \mu \mathrm{M}$ external glutamate. For the other 12 cells, however, the $\mathrm{K}^{+}$evoked current was net inward and became more inward in the presence of glutamate (Fig. $3 F$ ). Presumably in those cells the outward reversed uptake current component was superimposed on an inward $\mathrm{K}^{+}$-evoked current flowing through the potassium channels of the cell. Subtracting the current in the presence of glutamate from that in the absence of glutamate revealed the outward $\mathrm{K}^{+}$-evoked reversed uptake current (trace $\Delta I$ in Fig. $3 F)$. In cells that were cultured in the absence of doxycycline, and so did not express GLT-1, raising $[\mathrm{K}]_{\mathrm{o}}$ evoked an inward current that was unaffected by $200 \mu \mathrm{M}$ glutamate (four cells).

DHK also reduced the reversed uptake current. In six cells 200 $\mu \mathrm{M}$ DHK made the $\mathrm{K}^{+}$-evoked current less outward (or more inward) by an amount that was not significantly different from (1.04 \pm 0.12 times) the change produced by $200 \mu \mathrm{M}$ glutamate (the current changes were calculated by subtraction as in Fig. $3 F$ ).

\section{Changes of pH produced by GLT-1}

To determine whether, like the GLAST transporters in salamander glial cells and EAAC1 and EAAT3 transporters in oocytes (Bouvier et al., 1992; Kanai et al., 1995; Zerangue and Kavanaugh, 1996b), GLT-1 generates an intracellular acidification, we used the fluorescent pH-sensitive dye BCECF (see Materials and Methods). Applying L-glutamate or D-aspartate decreased the fluorescence of BCECF excited at $490 \mathrm{~nm}$ (Fig. $4 A, B$ ), but not that excited at $440 \mathrm{~nm}$ (Fig. $4 B$ ), showing that these amino acids that are transported by GLT- 1 evoke an intracellular acidification (seen in all nine cells for glutamate and 11 cells for D-aspartate, which showed a stable $\mathrm{pH}$ baseline). Glutamate (50 $\mu \mathrm{M}$ for $1 \mathrm{~min}$ ) decreased the fluorescence excited at 490 $\mathrm{nm}$ by $2.2 \pm 0.4 \%$ (in five cells clamped to $-63 \mathrm{mV}$ ), which corresponds to an acidification of 0.022 units according to an in vitro calibration (Rink et al., 1982).

The acidification produced by $50 \mu \mathrm{M}$ D-aspartate was reduced by $27 \pm 5 \%$ in three cells by the GLT-1 blocker DHK (200 $\mu \mathrm{M}$; data not shown). D-Aspartate is not metabolized inside the cell, and so the acidification cannot be produced by biochemical reactions downstream of uptake into the cell. In experiments on nine cells (including that in Fig. $4 C$ ) amiloride (1 mM) was present in the external solution, and in all experiments $\mathrm{HCO}_{3}{ }^{-}$was absent from the internal and external solutions to prevent any $\mathrm{pH}$ 

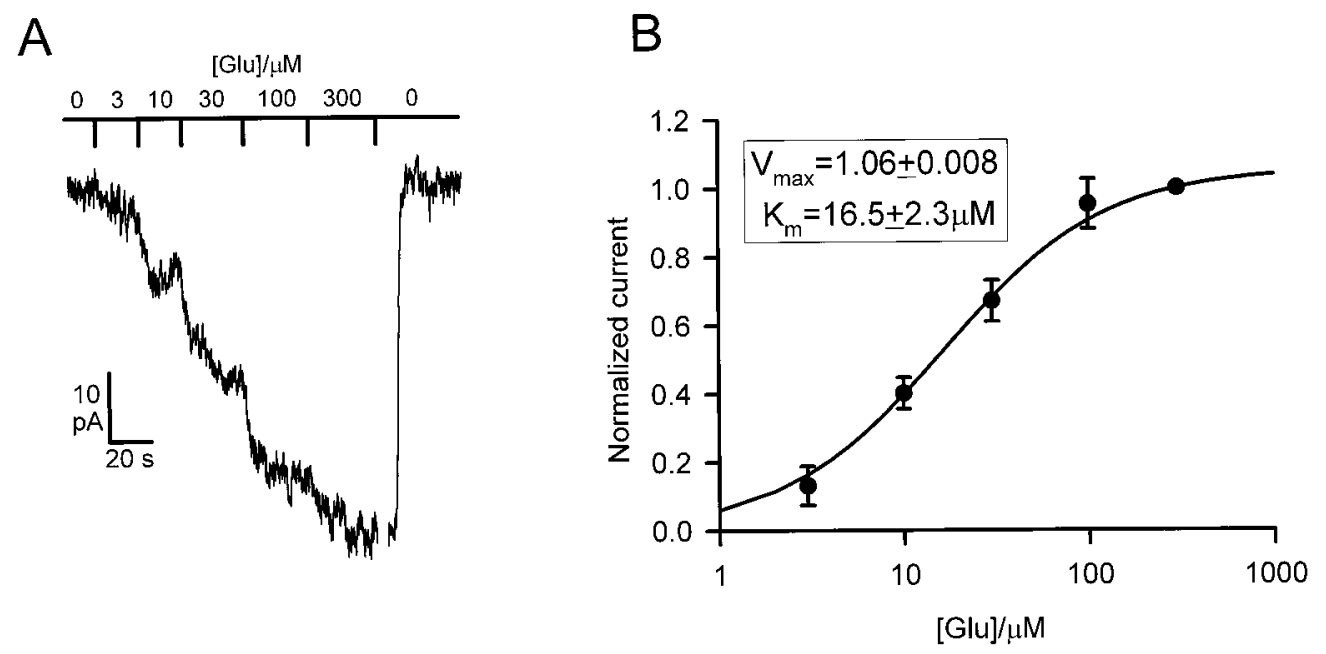

Figure 2. Glutamate dependence of uptake currents mediated by GLT-1. A, Current record from a cell superfused with solutions containing different glutamate concentrations (top line). B, Average dose-response curve for the uptake current in five cells. The smooth curve is a best-fit Michaelis-Menten curve with the parameters shown in the boxed inset.

changes being generated by $\mathrm{Na}^{+} / \mathrm{H}^{+}$exchange or $\mathrm{Na}^{+}-\mathrm{HCO}_{3}{ }^{-}$ cotransport secondary to a rise in $\left[\mathrm{Na}^{+}\right]_{\mathrm{i}}$ produced by uptake. Thus, the $\mathrm{pH}$ changes that were observed apparently are generated by GLT-1 transporting a $\mathrm{pH}$-changing ion, a conclusion we strengthen below.

Vandenberg et al. (1995) have suggested that the EAAT1 transporter may contain a tonically active conductance through which cations can pass, not coupled to glutamate transport. Conceivably such a conductance could be permeable to $\mathrm{H}^{+}$ions and, as is seen for the anion conductance in EAAT4 and EAAT5 transporters (Arriza et al., 1997; Fairman et al., 1995), could be activated by transporter substrates. However, in all three cells that were tested, we also observed an intracellular acidification (Fig. $4 C$ ) when the cell was held at $-20 \mathrm{mV}$, which is above the reversal potential for $\mathrm{H}^{+}$for the solutions used $\left(\mathrm{pH}_{\mathrm{o}}=7.7, \mathrm{pH}_{\mathrm{i}}=7.0, E_{\mathrm{H}}\right.$ $=-41 \mathrm{mV})$, showing that the movement of $\mathrm{H}^{+}\left(\right.$or $\left.\mathrm{OH}^{-}\right)$was coupled to glutamate entry and did not result from a passive $\mathrm{H}^{+}$ conductance activated by glutamate or D-aspartate (cf. Billups et al., 1996; Zerangue and Kavanaugh, 1996b).

The $\mathrm{pH}$ changes that were seen reached a plateau (implying no further entry of protons) on removing glutamate or aspartate, but they rarely reversed. This is because recovery depends on the rate of action of endogenous $\mathrm{pH}$ regulating carriers in the cell (mainly $\mathrm{Na}^{+} / \mathrm{H}^{+}$exchange in our solutions, which lacked bicarbonate). These recovery mechanisms apparently run much more slowly than the rate at which GLT-1 can acidify the cytoplasm.

\section{Reversal potential of the GLT-1 transporter}

We have shown above that GLT-1 can mediate forward or reversed uptake and thus can generate an inward or outward current, depending on the ionic and potential gradients across the membrane. Applying a nontransported blocker of GLT-1, like DHK (see Discussion), therefore should evoke a current change that is outward at very negative potentials (where the transporter is mediating forward uptake and generating an inward current) and inward at very positive potentials (where the transporter is running in reverse and generating an outward current). At some potential in between there will be no net glutamate and charge flux through the transporter, and DHK will evoke no current. This reversal potential for the transporter is determined by the ionic stoichiometry of the transporter (Zerangue and Kavanaugh, 1996b) as:

$$
\begin{aligned}
V_{\text {rev }}=\left\{R T /\left[F\left(n_{\mathrm{Na}}+n_{\mathrm{H}}-n_{\mathrm{glu}}-n_{\mathrm{K}}\right)\right]\right\}\left[n_{\mathrm{Na}} \ln \left(\mathrm{Na}_{\mathrm{o}} / \mathrm{Na}_{\mathrm{i}}\right)\right. \\
\left.+n_{\mathrm{H}} \ln \left(\mathrm{H}_{\mathrm{o}} / \mathrm{H}_{\mathrm{i}}\right)+n_{\mathrm{glu}} \ln \left(\mathrm{glu}_{\mathrm{o}} / \mathrm{glu}_{\mathrm{i}}\right)-n_{\mathrm{K}} \ln \left(\mathrm{K}_{\mathrm{o}} / \mathrm{K}_{\mathrm{i}}\right)\right],
\end{aligned}
$$

where $n_{\mathrm{Na}}$ (etc.) is the number of ions moving on each carrier cycle, $\mathrm{Na}_{\mathrm{o}}$ and $\mathrm{Na}_{\mathrm{i}}$ (etc.) are the concentrations of $\mathrm{Na}^{+}$(etc.) outside and inside the cell, $R$ is the gas constant, $T$ is the temperature, and $F$ is the Faraday constant.

This equation can only be used if all of the current change produced by DHK is attributable to the block of ion movements coupled to glutamate translocation. In the following experiments, therefore, we used solutions lacking $\mathrm{Cl}^{-}$(replaced by gluconate) to abolish any contribution from the anion conductance activated by the transporter (Wadiche et al., 1995a). A cation conductance that is tonically active in the absence of external glutamate (which might reflect cation flux resulting from activation of reversed uptake by glutamate inside the cell or might be attributable to a transporter cation conductance that occurs even without glutamate bound) has been reported for EAAC1 (homologous to EAAT3; Kanai et al., 1995) and EAAT1 (Vandenberg et al., 1995), but not for GLT-1 or its homolog EAAT2. In the absence of external glutamate (and in the absence of anions like $\mathrm{NO}_{3}{ }^{-}$ that are highly permeant through the anion conductance of the transporter), DHK evokes no current in GLT-1/Dd-B7 cells whole-cell-clamped with a pipette solution lacking glutamate (see Fig. $3 B$ ), which suggests that DHK only blocks charge movements coupled to glutamate translocation and that the reversal potential of the DHK-evoked current can be equated to that of the glutamate translocation part of the transporter (see Discussion for further consideration of this point).

Figure $5 A$ shows current changes at different voltages, resulting from the application of $200 \mu \mathrm{M}$ DHK to a cell studied with intracellular and extracellular solutions containing glutamate, $\mathrm{Na}^{+}$, and $\mathrm{K}^{+}$to allow both forward and reversed glutamate transport. At positive potentials DHK evokes an inward current shift. At negative potentials it evokes an outward shift. The mean reversal potential measured in 22 cells was $-12.2 \pm 1.6 \mathrm{mV}$. For 
A
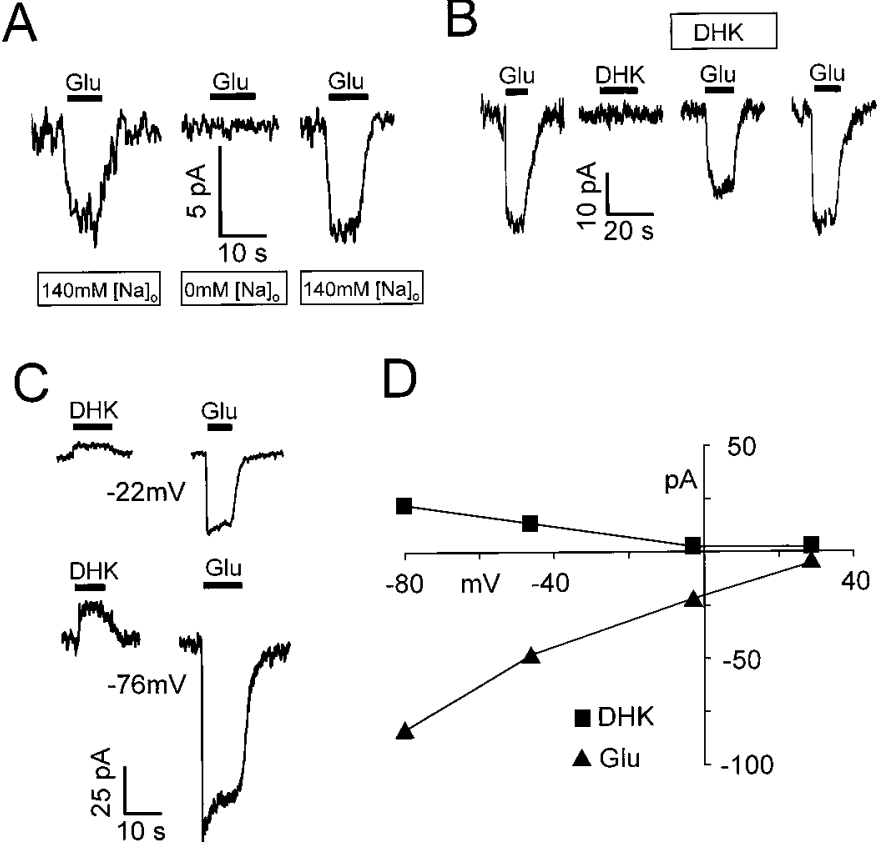

$E$

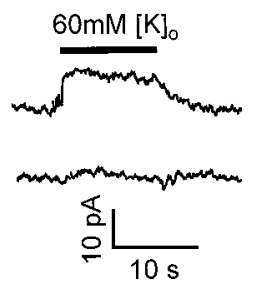

[glu $]_{\circ}$

$0 \mu \mathrm{M}$

$200 \mu \mathrm{M}$

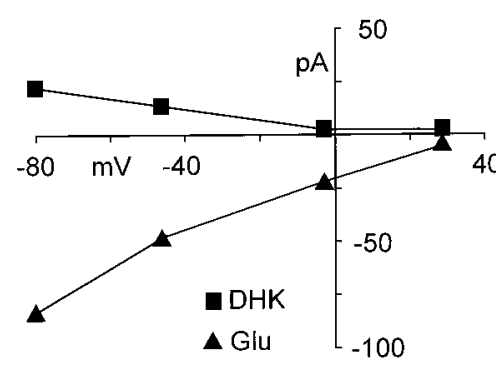

$\mathrm{F}$

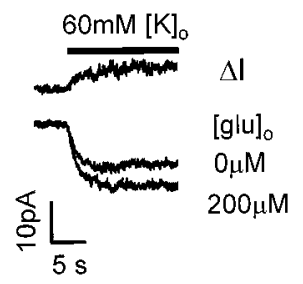

Figure 3. Properties of forward and reversed uptake mediated by GLT-1 in CHO cells. $A$, Sodium dependence: removing external $\mathrm{Na}^{+}$(replaced with choline) abolished the current evoked by glutamate (GLU; bars) at $-67 \mathrm{mV}$. B, Sensitivity to dihydrokainate $(D H K)$ with solutions containing $\mathrm{Cl}^{-}$as the main anion. After a control response to $300 \mu \mathrm{M}$ glutamate, $200 \mu \mathrm{M}$ DHK was found to evoke no current change. Applying glutamate in DHK evoked a current that was smaller than in control solution (note that the reduction produced by DHK is less than that quoted in the text for $200 \mu \mathrm{M}$ glutamate because [glutamate] was $300 \mu \mathrm{M}$ here). Applying glutamate again after the DHK was washed out evoked a response similar in size to the initial control. $C$, Responses to $200 \mu \mathrm{M}$ DHK and $200 \mu \mathrm{M}$ glutamate, using a pipette solution containing $130 \mathrm{mM} \mathrm{NO}_{3}{ }^{-}$. Left panels, DHK evoked an outward current that was smaller at more positive potentials, i.e., a conductance decrease. Right panels, Glutamate evoked an inward current that was larger at more negative potentials, i.e., a conductance increase. $D$, Voltage dependence of responses obtained as in $C$ (from a different cell; similar results were obtained in three cells). $E, F$, Reversed uptake, alone $(E)$ or superimposed on an inward current through $\mathrm{K}+$ channels $(F)$, evoked by raising $\left[\mathrm{K}^{+}\right]_{\mathrm{o}}$ from 0 to $60 \mathrm{~mm}$ around cells clamped with a pipette containing $10 \mathrm{mM}$ Na-glutamate. $E$, Raising $\left[\mathrm{K}^{+}\right]_{\mathrm{o}}$ evoked an outward current (at $+40 \mathrm{mV}$ ) that was suppressed by $200 \mu \mathrm{M}$ external glutamate. $F$, In another cell, raising $\left[\mathrm{K}^{+}\right]_{\mathrm{o}}$ evoked an inward current (at $0 \mathrm{mV}$ ) that was increased by $200 \mu \mathrm{M}$ external glutamate. Subtracting the current in the presence from that in the absence of glutamate revealed the outward $\mathrm{K}^{+}$-evoked reversed uptake current component $(\Delta I)$. The return of the current changes to baseline is not shown, because the duration of the $\left[\mathrm{K}^{+}\right]_{\mathrm{o}}$ elevation that was applied was different in the presence and absence of glutamate.

comparison, for the ionic conditions that were used, Equation 1 predicts a reversal potential of -11.9 or $-54.1 \mathrm{mV}$ for three or two $\mathrm{Na}^{+}$being cotransported with one $\mathrm{H}^{+}$and one glu ${ }^{-}$and with one $\mathrm{K}^{+}$being countertransported (predictions for some other possible stoichiometries are given in Table 1). Thus, the

A

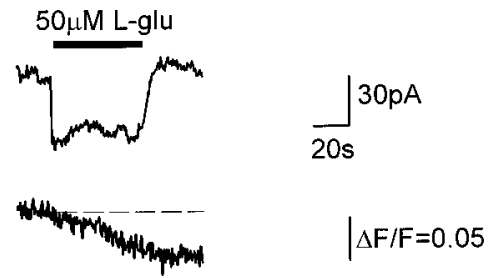

B
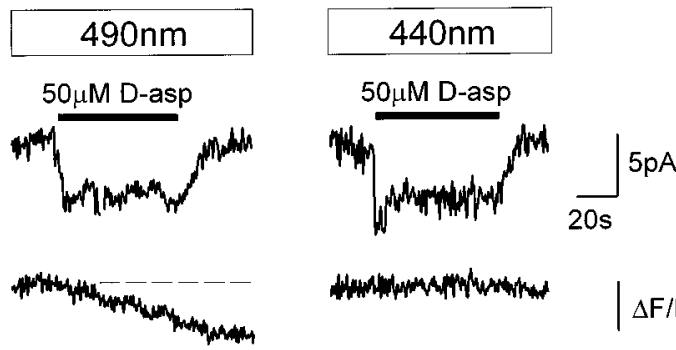

Hom

$\Delta \mathrm{F} / \mathrm{F}=0.015$

C
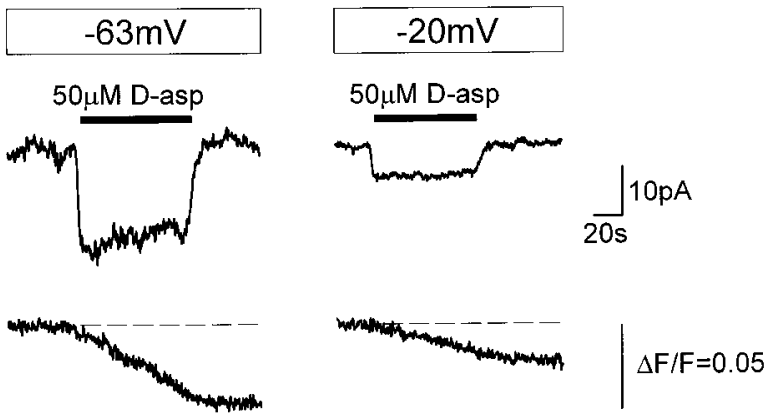

Figure 4. Changes of $\mathrm{pH}$ generated by GLT-1. For each panel the top trace is the membrane current, and the bottom trace is the BCECF fluorescence $(F)$, quantified as the fractional change $\Delta F / F$. In vitro calibration (Rink et al., 1982) indicates that a $\Delta F / F$ of 0.05 corresponds to a $\mathrm{pH}$ change of 0.05 units. $A$, Change of fluorescence of BCECF (excited at 490 and emitted at $530 \mathrm{~nm}$ ) and membrane current evoked by $50 \mu \mathrm{M}$ glutamate in a cell clamped to $-63 \mathrm{mV}$. When glutamate evokes a step change of uptake current, a change in the slope of the fluorescence record is seen (as expected if a proton influx accompanying uptake is proportional to the uptake current). $B$, Comparison of BCECF fluorescence and membrane current (at $-63 \mathrm{mV}$ ) changes that are seen when excitation is at 440 and $490 \mathrm{~nm}$ during the application of D-aspartate $(50 \mu \mathrm{M})$. D-Aspartate always evokes an inward current but produces no fluorescence change with $440 \mathrm{~nm}$ excitation. The small break in the current trace for $490 \mathrm{~nm}$ shows where an electrical artifact was removed. $C$, D-Aspartate evokes a $\mathrm{pH}$ change in a cell clamped to $-20 \mathrm{mV}$, i.e., above the reversal potential for $\mathrm{H}^{+}(-41 \mathrm{mV})$, as well as at more negative potentials. For this experiment $1 \mathrm{~mm}$ amiloride was present in the superfusion solution.

reversal potential observed is consistent with $n_{\mathrm{Na}}=3$, and $n_{\text {glu }}=$ $n_{\mathrm{K}}=n_{\mathrm{H}}=1$.

\section{Effect of ion concentration changes on the reversal potential}

From Equation 1 the predicted change in reversal potential when $\left[\mathrm{Na}^{+}\right]_{\mathrm{o}}$ is changed from value $\left[\mathrm{Na}^{+}\right]_{\mathrm{o}}{ }^{1}$ to value $\left[\mathrm{Na}^{+}\right]_{\mathrm{o}}{ }^{2}$ is:

$\Delta V_{\mathrm{Na}}=$

$\left(n_{\mathrm{Na}} R T\right) /\left[F\left(n_{\mathrm{Na}}+n_{\mathrm{H}}-n_{\mathrm{glu}}-n_{\mathrm{K}}\right)\right] \ln \left\{\left[\mathrm{Na}^{+}\right]_{\mathrm{o}}{ }^{2} /\left[\mathrm{Na}^{+}\right]_{\mathrm{o}}{ }^{1}\right\}$. 
A

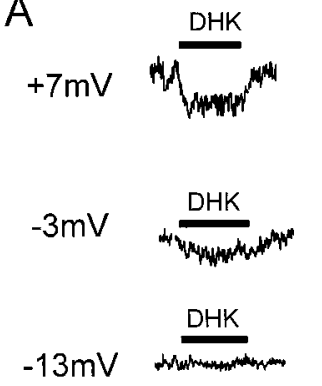

$-23 \mathrm{mV} \frac{\mathrm{DHK}}{\mathrm{m} N \mathrm{~min}}$

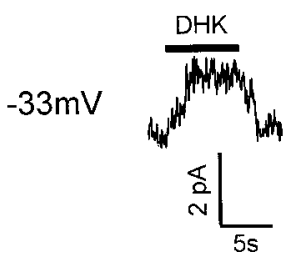

B
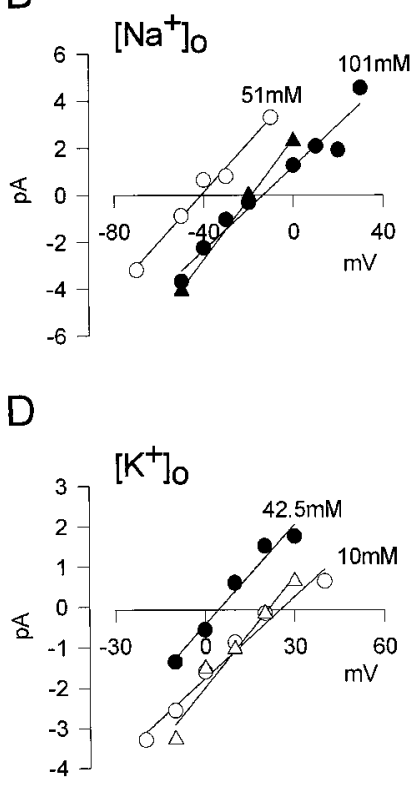

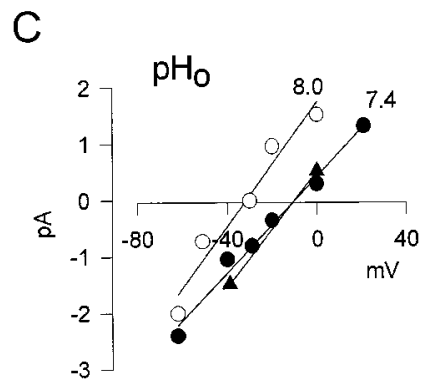

$\mathrm{E}$

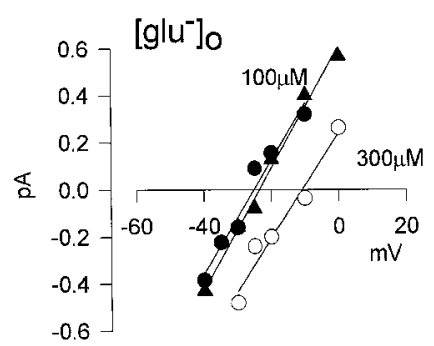

Figure 5. Reversal potential of the transporter and its substrate dependence. $A$, Specimen data showing the current changes produced by dihydrokainate $(D H K ; 200 \mu \mathrm{M})$ at various potentials (shown by each trace) in control solution (containing $101 \mathrm{mM} \mathrm{Na}^{+}, 42.5 \mathrm{~mm} \mathrm{~K} \mathrm{~K}^{+}$, and $100 \mu \mathrm{M}$ glutamate, $\mathrm{pH} 7.4$ ). At negative potentials the transporter moves glutamate and net positive charge in the inward direction, and DHK produces an outward current. At positive potentials the transporter runs in the other direction, and DHK produces an inward current. The amplitudes of current changes like this are plotted with the opposite sign in $B-D$ to show the current that is blocked by DHK. $B-D$, Shifts of reversal potential of the current suppressed by DHK, produced by altering the external concentrations of $\mathrm{Na}^{+}, \mathrm{H}^{+}, \mathrm{K}^{+}$, and glutamate. Straight lines are linear regression fits to the data. $B$, Voltage dependence of the transporter current in control solution with $101 \mathrm{mM}\left[\mathrm{Na}^{+}\right]_{\mathrm{o}}$ ( filled circles), then in solution with reduced $\left[\mathrm{Na}^{+}\right]_{\mathrm{o}}$ (open circles), and then again in control solution (filled triangles). $C$, Similar data but for a reduction of $\left[\mathrm{H}^{+}\right]_{\mathrm{o}}\left(\mathrm{pH}_{\mathrm{o}}=8.0\right)$. $D, I-V$ relation for the DHK-suppressed transporter current in solution with reduced $\left[\mathrm{K}^{+}\right]_{\mathrm{o}}(10 \mathrm{mM}$; open circles $)$, then in control solution $\left(42.5 \mathrm{mM}\left[\mathrm{K}^{+}\right]_{\mathrm{o}}\right.$; filled circles $)$, and then in $10 \mathrm{mM}\left[\mathrm{K}^{+}\right]_{\mathrm{o}}$ again (open triangles). $E$, Data as in $B$ but for an increase of external glutamate concentration from the control value (100 $\mu \mathrm{M})$ to $300 \mu \mathrm{M}$. Specimen data are shown for single cells (rather than averaged over all cells) for each solution change because of small variations in the initial reversal potential in each cell (quantified in Table 1), presumably reflecting small differences in intracellular $\left[\mathrm{Na}^{+}\right],\left[\mathrm{H}^{+}\right],\left[\mathrm{K}^{+}\right]$, or $\left[\mathrm{Glu}^{-}\right]$, which would add noise to the shift of the $I-V$ relation. The theoretical predictions (Eqs. 2-5) for the reversal potential shifts are independent of the exact intracellular substrate concentrations and are compared with mean data (averaged over all cells) in Table 1.

Table 1. Comparison of experimental data on GLT-1 reversal potential with theoretical predictions for different stoichiometries

\begin{tabular}{llllll} 
& & \multicolumn{2}{l}{ Theory } & \\
\cline { 2 - 6 } & Experiments & $3 \mathrm{Na}^{+}, \mathrm{H}^{+}, \mathrm{glu}^{-} / \mathrm{K}^{+}$ & $2 \mathrm{Na}^{+}, \mathrm{H}^{+}, \mathrm{glu}^{-} / \mathrm{K}^{+}$ & $3 \mathrm{Na}^{+}, 2 \mathrm{H}^{+}, \mathrm{glu}^{-} / \mathrm{K}^{+}$ & $5 \mathrm{Na}^{+}, \mathrm{H}^{+}, 2 \mathrm{glu}^{-} / \mathrm{K}^{+}$ \\
\hline Control $E_{\text {rev }}$ & $-12.2 \pm 1.6(\mathrm{n}=22)$ & $-11.9(p=0.85)$ & $-54.1\left(p=9 \times 10^{-18}\right)$ & $-15.8\left(p=3 \times 10^{-2}\right)$ & $-27.1\left(p=3.9 \times 10^{-9}\right)$ \\
$\Delta E_{\text {rev }}\left(\Delta[\mathrm{Na}]_{\mathrm{o}}\right)$ & $-27.8 \pm 2.5(\mathrm{n}=7)$ & $-26.3(p=0.56)$ & $-35.1\left(p=2.6 \times 10^{-2}\right)$ & $-17.5\left(p=5.9 \times 10^{-3}\right)$ & $-29.2(p=0.59)$ \\
$\Delta E_{\text {rev }}\left(\Delta[\mathrm{H}]_{\mathrm{o}}\right)$ & $-19.3 \pm 3.2(\mathrm{n}=6)$ & $-17.7(p=0.66)$ & $-35.5\left(p=3.9 \times 10^{-3}\right)$ & $-23.6(p=0.23)$ & $-11.8\left(p=6.8 \times 10^{-2}\right)$ \\
$\Delta E_{\text {rev }}\left(\Delta[\mathrm{K}]_{\mathrm{o}}\right)$ & $+14.6 \pm 2.6(\mathrm{n}=11)$ & $+18.6(p=0.16)$ & $+37.1\left(p=6.4 \times 10^{-6}\right)$ & $+12.4(p=0.41)$ & $+12.4(p=0.41)$ \\
$\Delta E_{\text {rev }}\left(\Delta[\mathrm{glu}]_{\mathrm{o}}\right)$ & $+15.1 \pm 1.6(\mathrm{n}=7)$ & $+14.1(p=0.57)$ & $+28.2\left(p=2.1 \times 10^{-4}\right)$ & $+9.4\left(p=1.3 \times 10^{-2}\right)$ & $+18.8\left(p=6.5 \times 10^{-2}\right)$ \\
\hline
\end{tabular}

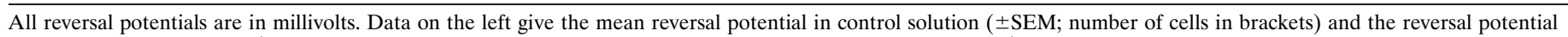

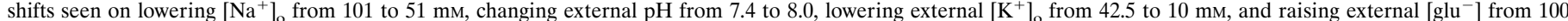

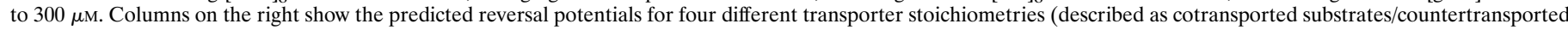
substrate). In brackets after each value is shown the $p$ value from a two-tailed $t$ test comparing the theoretical prediction with the experimental data.

(Note that this depends only on the old and new values of $\left[\mathrm{Na}^{+}\right]_{\mathrm{o}}$ and on the numbers of ions transported.) For $\left[\mathrm{Na}^{+}\right]_{\mathrm{o}}{ }^{1}=101 \mathrm{mM}$ and $\left[\mathrm{Na}^{+}\right]_{\mathrm{o}}{ }^{2}=51 \mathrm{mM}$, as in our experiments, Equation 2 predicts a shift of -26.3 or $-35.1 \mathrm{mV}$, respectively, if three or two $\mathrm{Na}^{+}$ are cotransported and $n_{\text {glu }}=n_{\mathrm{K}}=n_{\mathrm{H}}=1$. Figure $5 B$ shows specimen $I-V$ relations for the DHK-blocked current in a cell studied with these two values of $\left[\mathrm{Na}^{+}\right]_{\text {o }}$ (note that at positive potentials the inward current shift produced by DHK is plotted as outward, i.e., the size of the current blocked is plotted). Lowering $\left[\mathrm{Na}^{+}\right]_{\mathrm{o}}$ shifted the reversal potential negative by $24 \mathrm{mV}$ in this cell and by $27.8 \pm 2.5 \mathrm{mV}$ in seven cells, consistent with $n_{\mathrm{Na}}=3$, and $n_{\mathrm{glu}}=n_{\mathrm{K}}=n_{\mathrm{H}}=1$ (other possibilities are assessed in Table 1 and discussed below).
From Equation 1 the predicted change in reversal potential when $\left[\mathrm{H}^{+}\right]_{\mathrm{o}}$ is changed from value $\left[\mathrm{H}^{+}\right]_{\mathrm{o}}{ }^{1}$ to value $\left[\mathrm{H}^{+}\right]_{\mathrm{o}}{ }^{2}$ is:

$$
\begin{aligned}
\Delta V_{\mathrm{H}}= & \\
& \left(n_{\mathrm{H}} R T\right) /\left[F\left(n_{\mathrm{Na}}+n_{\mathrm{H}}-n_{\mathrm{glu}}-n_{\mathrm{K}}\right)\right] \ln \left\{\left[\mathrm{H}^{+}\right]_{\mathrm{o}}{ }^{2} /\left[\mathrm{H}^{+}\right]_{\mathrm{o}}{ }^{1}\right\} .
\end{aligned}
$$

For $\left[\mathrm{H}^{+}\right]_{\mathrm{o}}{ }^{1}=10^{-7.4}$ and $\left[\mathrm{H}^{+}\right]_{\mathrm{o}}{ }^{2}=10^{-8} \mathrm{M}$, as in our experiments, Equation 3 predicts a shift of -17.7 or $-35.5 \mathrm{mV}$, respectively, if three or two $\mathrm{Na}^{+}$are cotransported and $n_{\mathrm{glu}}=n_{\mathrm{K}}=n_{\mathrm{H}}$ $=1$. Figure $5 C$ shows specimen $I-V$ relations for the DHKblocked current in a cell studied with these two values of $\left[\mathrm{H}^{+}\right]_{\mathrm{o}}$. Changing the external $\mathrm{pH}$ shifted the reversal potential negative 
by $21 \mathrm{mV}$ in this cell and by $19.3 \pm 3.2 \mathrm{mV}$ in six cells, consistent with $n_{\mathrm{Na}}=3$, and $n_{\text {glu }}=n_{\mathrm{K}}=n_{\mathrm{H}}=1$.

From Equation 1 the predicted change in reversal potential when $\left[\mathrm{K}^{+}\right]_{\mathrm{o}}$ is changed from value $\left[\mathrm{K}^{+}\right]_{\mathrm{o}}{ }^{1}$ to value $\left[\mathrm{K}^{+}\right]_{\mathrm{o}}{ }^{2}$ is:

$$
\begin{aligned}
& \Delta V_{\mathrm{K}}= \\
& \quad\left(-n_{\mathrm{K}} R T\right) /\left[F\left(n_{\mathrm{Na}}+n_{\mathrm{H}}-n_{\mathrm{glu}}-n_{\mathrm{K}}\right)\right] \ln \left\{\left[\mathrm{K}^{+}\right]_{\mathrm{o}}{ }^{2} /\left[\mathrm{K}^{+}\right]_{\mathrm{o}}{ }^{1}\right\} .
\end{aligned}
$$

For $\left[\mathrm{K}^{+}\right]_{\mathrm{o}}{ }^{1}=42.5$ and $\left[\mathrm{K}^{+}\right]_{\mathrm{o}}{ }^{2}=10 \mathrm{~mm}$, as in our experiments, Equation 4 predicts a shift of 18.6 or $37.1 \mathrm{mV}$, respectively, if three or two $\mathrm{Na}^{+}$are cotransported and $n_{\text {glu }}=n_{\mathrm{K}}=n_{\mathrm{H}}=1$. Figure $5 D$ shows specimen $I-V$ relations for the DHK-blocked current in a cell studied with these two values of $\left[\mathrm{K}^{+}\right]_{\mathrm{o}}$. Changing $\left[\mathrm{K}^{+}\right]_{\mathrm{o}}$ shifted the reversal potential positive by $20 \mathrm{mV}$ in this cell and by $14.6 \pm 2.6 \mathrm{mV}$ in 11 cells, consistent with $n_{\mathrm{Na}}=3$, and $n_{\text {glu }}$ $=n_{\mathrm{K}}=n_{\mathrm{H}}=1$.

From Equation 1 the predicted change in reversal potential when $\left[\mathrm{glu}^{-}\right]_{\mathrm{o}}$ is changed from value $\left[\mathrm{glu}^{-}\right]_{\mathrm{o}}{ }^{1}$ to value $\left[\mathrm{glu}^{-}\right]_{\mathrm{o}}{ }^{2}$ is:

$$
\begin{aligned}
& \Delta V_{\mathrm{glu}}= \\
& \quad\left(n_{\mathrm{glu}} R T\right) /\left[F\left(n_{\mathrm{Na}}+n_{\mathrm{H}}-n_{\mathrm{glu}}-n_{\mathrm{K}}\right)\right] \ln \left\{\left[\mathrm{glu}^{-}\right]_{\mathrm{o}}{ }^{2} /\left[\mathrm{glu}^{-}\right]_{\mathrm{o}}{ }^{1}\right\} .
\end{aligned}
$$

For $\left[\mathrm{glu}^{-}\right]_{\mathrm{o}}{ }^{1}=0.1$ and $\left[\mathrm{glu}^{-}\right]_{\mathrm{o}}{ }^{2}=0.3 \mathrm{~mm}$, as in our experiments, Equation 5 predicts a shift of 14.1 or $28.2 \mathrm{mV}$, respectively, if three or two $\mathrm{Na}^{+}$are cotransported and $n_{\text {glu }}=n_{\mathrm{K}}=n_{\mathrm{H}}=1$. Figure $5 E$ shows specimen $I-V$ relations for the DHK-blocked current in a cell studied with these two values of $\left[\mathrm{glu}^{-}\right]_{\mathrm{o}}$. Raising the external glutamate concentration shifted the reversal potential positive by $14 \mathrm{mV}$ in this cell and by $15.1 \pm 1.6 \mathrm{mV}$ in seven cells, consistent with $n_{\mathrm{Na}}=3$, and $n_{\text {glu }}=n_{\mathrm{K}}=n_{\mathrm{H}}=1$.

\section{Estimation of the stoichiometry of GLT-1}

Table 1 summarizes the experimentally observed reversal potential of the DHK-blocked current in the control external solution and the shifts in reversal potential evoked by altering the external sodium, proton, potassium, and glutamate concentrations. It also summarizes the theoretical predictions for these parameters of several possible transporter stoichiometries, together with $p$ values for $t$ tests comparing the experimental data with the prediction of each stoichiometry.

Comparing the data first with the predictions for $n_{\mathrm{Na}}=3$ or 2 sodium ions cotransported, assuming that $n_{\mathrm{H}}=n_{\mathrm{K}}=n_{\mathrm{glu}}=1$, it is clear that the reversal potential in control solution and the reversal potential shifts produced by altering each of the four transported species are all consistent with $n_{\mathrm{Na}}=3$ and completely inconsistent with $n_{\mathrm{Na}}=2$.

We then considered whether other possible stoichiometries might be consistent with the data. All possible stoichiometries were considered that had (1) the sum of the number of $\mathrm{Na}^{+}$and of $\mathrm{H}^{+}$transported $\leq 6$ [going up to such large numbers was considered justified because GLT-1 is thought to operate as a trimer (Haugeto et al., 1996), and conceivably several ions could bind to each trimer]; (2) at least one $\mathrm{Na}^{+}$and one glu ${ }^{-}$transported (for consistency with radiotracing data); and (3) a net positive charge moving into the cell with glutamate (as seen electrophysiologically even with the anion conductance abolished by chloride removal). These constraints led us to consider 175 possible stoichiometries, which were narrowed to those shown in Table 1 as described in Materials and Methods. Some stoichiometries (other than $n_{\mathrm{Na}}=3, n_{\mathrm{H}}=1, n_{\mathrm{K}}=1, n_{\text {glu }}=1$ ) could predict certain individual values close to what was observed, but none of them predicted accurately both the control reversal potential and all four reversal potential shifts produced by altering the ion gradients. For example, for the postulated stoichiometry $n_{\mathrm{Na}}=5$, $n_{\mathrm{H}}=1, n_{\mathrm{K}}=1, n_{\mathrm{glu}}=2$, the predictions are reasonable for the reversal potential shifts produced by altering $\left[\mathrm{Na}^{+}\right]$and $\left[\mathrm{K}^{+}\right]$but less good for the control reversal potential and the shifts produced by altering $\left[\mathrm{H}^{+}\right]_{\mathrm{o}}$ and $\left[\mathrm{glu}^{-}\right]_{\mathrm{o}}$. The two stoichiometries (other than $n_{\mathrm{Na}}=3, n_{\mathrm{H}}=1, n_{\mathrm{K}}=1, n_{\mathrm{glu}}=1$ ) that minimized the differences between the observed and predicted values were (1) $n_{\mathrm{Na}}=5, n_{\mathrm{H}}=1, n_{\mathrm{K}}=1, n_{\mathrm{glu}}=2$ and (2) $n_{\mathrm{Na}}=3, n_{\mathrm{H}}=2, n_{\mathrm{K}}=$ $1, n_{\text {glu }}=1$. For each of these, however, and for other stoichiometries with predictions that were slightly further from the data (which could not be fit into Table 1), $t$ tests comparing the observed and predicted values ruled them out as plausible stoichiometries (Table 1). We conclude that the stoichiometry $n_{\mathrm{Na}}=$ $3, n_{\mathrm{H}}=1, n_{\mathrm{K}}=1, n_{\mathrm{glu}}=1$ predicts results that are not significantly different from our data, whereas all other stoichiometries do not.

\section{DISCUSSION}

\section{Currents generated by GLT-1 transporters in GLT-1/Dd-B7 cells}

The voltage, $\mathrm{Na}^{+}$and $\mathrm{K}^{+}$dependence, and the pharmacology of the glutamate-evoked current in GLT-1/Dd-B7 cells are similar to those seen for GLT-1 (or its human equivalent EAAT2) in preparations derived from native brain or when expressed heterologously in oocytes or COS-7 cells (Kanner and Sharon, 1978; Pines et al., 1992; Arriza et al., 1994; Wadiche et al., 1995a).

Glutamate transporters can generate membrane current both by the movements of ions coupled to glutamate transport and by the activation of an anion conductance (Wadiche et al., 1995a). The current mediated by GLT- 1 and its homolog EAAT2 is still inward at $+40 \mathrm{mV}$ (see Fig. 1; Wadiche et al., 1995a), and removing external $\mathrm{Cl}^{-}$has no effect on the current generated by EAAT2 (Wadiche et al., 1995a). By contrast, EAAT1 and EAAT3 show an outward current at positive potentials that is abolished by the removal of external $\mathrm{Cl}^{-}$. These data suggest that GLT-1/EAAT2 normally activates little anion conductance as compared with EAAT1 and EAAT3. In the presence of the much more permeable anion $\mathrm{NO}_{3}{ }^{-}$, however, the anion conductance may be significant. Our observation that DHK suppresses a conductance in cells clamped with pipettes containing $\mathrm{NO}_{3}{ }^{-}$is consistent with the suggestion of Bergles and Jahr (1997) that the GLT-1 anion conductance is tonically active in the absence of external glutamate.

\section{Stoichiometry of GLT-1}

The stoichiometry of GLT-1 was determined by the method of Zerangue and Kavanaugh (1996b) in which the reversal potential of the current blocked by a nontransported glutamate analog (DHK or kainate) is measured in various ionic conditions. The idea is that, with all of the transporter substrates (glutamate, $\mathrm{Na}^{+}, \mathrm{K}^{+}$, and $\mathrm{H}^{+}$) present on both sides of the membrane, forward uptake will occur at very negative membrane potentials, reversed uptake will occur at very positive membrane potentials, and at an intermediate potential determined by the transporter stoichiometry there will be no net glutamate movement. DHK blocks forward uptake at negative potentials, giving an outward current shift, and blocks reversed uptake at positive potentials, giving an inward current shift, but at the transporter reversal potential DHK does not change the membrane current (see Fig. $5 A$ ). Measuring this null potential in various ionic conditions allows the stoichiometry to be deduced from Equations 1-5. 
This approach requires that several conditions hold. First, DHK must not be transported in place of glutamate. This is shown by the fact that DHK generates no current on its own (see Fig. 3B; Wang et al., 1998) and that kainate (a close analog of DHK, which also relatively specifically blocks GLT-1) is not transported into cells expressing the GLT-1 homolog EAAT2 (Arriza et al., 1994). Second, DHK must affect no glutamateactivated current other than that caused by ion movements coupled to glutamate transport. This is satisfied because GLT-1/ Dd-B7 cells generate no glutamate-gated currents other than via GLT-1 activation (Levy et al., 1998), and, although the contribution of an anion conductance to the current is small (see above), we performed all the stoichiometry experiments with the anion conductance suppressed by the removal of $\mathrm{Cl}^{-}$. Finally, there must be no "slippage" in the coupling of the ions cotransported with glutamate. For example, if $\mathrm{Na}^{+}$could be transported across the membrane in the absence of glutamate binding, then the transporter would generate a tonic inward current. Adding glutamate or DHK might decrease this current (producing a current change unrelated to glutamate movement) by diverting the transporter to a state in which $\mathrm{Na}^{+}$crosses the membrane with glutamate or (in the case of DHK) not at all. This is unlikely to occur for GLT-1, because DHK alone generates no current (in the absence of $\mathrm{NO}_{3}{ }^{-}$; see Fig. $3 B$ ). It might be argued that if DHK could only bind to the transporter after glutamate has bound, it would not generate any current change in the absence of glutamate, but then DHK would block better at high glutamate concentrations whereas, in fact, the DHK block of glutamate uptake by GLT-1/EAAT2 is competitive (less block at higher glutamate doses; Arriza et al., 1994), implying that DHK and glutamate bind to the same site. We conclude that the conditions necessary for the method to work do hold.

Using this approach, we found that each glutamate is transported into the cell with three $\mathrm{Na}^{+}$and one $\mathrm{H}^{+}$, while one $\mathrm{K}^{+}$is transported in the other direction so that two net positive charges move with each glutamate; this is the same stoichiometry that Zerangue and Kavanaugh (1996b) found for EAAT3 transporters expressed in oocytes. This is the first time that the GLT-1 stoichiometry has been shown to involve cotransport of a proton. The resulting glutamate uptake-evoked acidification of the cytoplasm of astrocytes expressing GLT-1 could constitute a signal regulating glial metabolism during periods of elevated extracellular glutamate concentration. Glutamate generates an uptakemediated intracellular acidification in hippocampal slices (Amato et al., 1994b), which is likely to be dominated by $\mathrm{pH}$ changes in astrocytes, because GLT-1 is more abundant than neuronal uptake carriers (Haugeto et al., 1996).

\section{Discrepancies with earlier data}

Radiotracing experiments on unidentified glutamate transporters in cell lines suggested that two $\mathrm{Na}^{+}$are cotransported into the cell with each glutamate ion (Baetge et al., 1979; Stallcup et al., 1979) rather than three $\mathrm{Na}^{+}$as determined here. Conceivably, this discrepancy arises from some of the radioactive $\mathrm{Na}^{+}$, which enters the cell on the glutamate transporter, leaving the cell again through ion channels or exchangers (although the $\mathrm{Na} / \mathrm{K}$ pump was blocked in those experiments). Similarly, Erecinska et al. (1983) found that the equilibrium accumulation of D-aspartate in synaptosomes was proportional to $\left[\mathrm{Na}^{+}\right]_{\mathrm{o}}{ }^{2}$, suggesting the transport of two $\mathrm{Na}^{+}$, but this might result from $\left[\mathrm{Na}^{+}\right]_{i}$ increasing when $\left[\mathrm{Na}^{+}\right]_{\mathrm{o}}$ was raised, decreasing the apparent dependence on $\mathrm{Na}^{+}$. A less easily resolvable discrepancy [both of this paper and of Zerangue and Kavanaugh (1996b)] is with the work of Wadiche et al. (1995a), who measured a charge entry per transported D-aspartate (with $\mathrm{Cl}^{-}$removed) that was closer to one than two in oocytes expressing either the GLT-1 homolog EAAT2 or EAAT3. Similarly, Kanai et al. (1995) found entry of one charge and two $\mathrm{Na}^{+}$per glutamate in oocytes expressing EAAC1. At present the reason for these differences is uncertain.

\section{Implications of the GLT-1 stoichiometry for the increase of [glu] in ischemia}

The lowest value of $[\mathrm{glu}]_{\mathrm{o}}$ that can be maintained by a transporter cotransporting one glutamate anion, three $\mathrm{Na}^{+}$, and one $\mathrm{H}^{+}$and countertransporting one $\mathrm{K}^{+}$is (by rearranging Eq. 1):

$$
\begin{aligned}
& {[\mathrm{glu}]_{\mathrm{o}}=[\mathrm{glu}]_{\mathrm{i}}\left(\left[\mathrm{Na}^{+}\right]_{\mathrm{i}} /\left[\mathrm{Na}^{+}\right]_{\mathrm{o}}\right)^{3} } \\
& {\left.\left[\mathrm{H}^{+}\right]_{\mathrm{i}} /\left[\mathrm{H}^{+}\right]_{\mathrm{o}}\right)\left(\left[\mathrm{K}^{+}\right]_{\mathrm{o}} /\left[\mathrm{K}^{+}\right]_{\mathrm{i}}\right) \exp (2 V F / R T) . }
\end{aligned}
$$

Under normal conditions this equation predicts a minimum maintainable $[\mathrm{glu}]_{\mathrm{o}}$ of $\sim 2 \mathrm{~nm}$ (Zerangue and Kavanaugh, 1996a). During brain ischemia the extracellular potassium concentration rises to $\sim 60 \mathrm{~mm}$ and $\left[\mathrm{Na}^{+}\right]_{\mathrm{o}}$ falls by a similar amount (from 144 to $\sim 87 \mathrm{~mm}$; Siesjö, 1990). Internal $\left[\mathrm{Na}^{+}\right]$and $\left[\mathrm{K}^{+}\right]$rise and fall correspondingly, but by less because of the greater intracellular volume fraction; if the extracellular volume fraction is $0.2,\left[\mathrm{Na}^{+}\right]_{\mathrm{i}}$ will rise and $\left[\mathrm{K}^{+}\right]_{\mathrm{i}}$ will fall by $\sim 14 \mathrm{~mm}$. In addition, the membrane potential depolarizes past $-20 \mathrm{mV}$. This rundown of the transmembrane gradients driving uptake will result in glutamate transporters running backward and raising the extracellular glutamate concentration until a new equilibrium is reached (Attwell et al., 1993; Szatkowski and Attwell, 1994).

Zerangue and Kavanaugh (1996b) have suggested that the extra accumulative power conferred by cotransport of three, rather than two, $\mathrm{Na}^{+}$will allow the transporters to continue to remove extracellular glutamate even in the perturbed ionic conditions of ischemia. To estimate how high the minimum maintainable $[\mathrm{glu}]_{\mathrm{o}}$ will rise when $\left[\mathrm{K}^{+}\right]_{\mathrm{o}}$ rises in ischemic conditions, we assume that initially $\left[\mathrm{Na}^{+}\right]_{\mathrm{i}}=25 \mathrm{~mm}$ and $\left[\mathrm{K}^{+}\right]_{\mathrm{i}}=119 \mathrm{~mm}$, so that in ischemia $\left[\mathrm{Na}^{+}\right]_{\mathrm{i}}$ rises to $39 \mathrm{~mm}$ and $\left[\mathrm{K}^{+}\right]_{\mathrm{i}}$ falls to $105 \mathrm{~mm}$ (Ballanyi et al., 1987; Friedman and Haddad, 1994), that the membrane potential is given by the Nernst potential for $\mathrm{K}^{+}$, and that although the intra- and extracellular $\mathrm{pH}$ shift acid in ischemia, they do so at the same rate so that throughout $\left[\mathrm{H}^{+}\right]_{\mathrm{i}} /\left[\mathrm{H}^{+}\right]_{\mathrm{o}}$ $=2$. We also need to assume an average value for $[\mathrm{glu}]_{\mathrm{i}}$. As discussed in Attwell et al. (1993), this is complicated by the likelihood of the value being different in neurons and glia (but becoming less different in ischemia when glial $[\mathrm{glu}]_{\mathrm{i}}$ rises $)$. As a compromise we use the value $[\mathrm{glu}]_{\mathrm{i}}=3 \mathrm{~mm}$ (Storm-Mathisen et al., 1992; Attwell et al., 1993). With this and with the ion concentrations listed above, Equation 6 predicts that, when $\left[\mathrm{K}^{+}\right]_{\mathrm{o}}$ rises in ischemia to $60 \mathrm{~mm}$, the lowest that glutamate transporters can hold [glu] down to in equilibrium is $112 \mu \mathrm{M}$. This value was calculated assuming a commonly quoted extracellular volume fraction of $20 \%$ (Nicholson and Phillips, 1981); if this value is reduced to $13 \%$, as measured for hippocampus (McBain et al., 1990), with corresponding alterations in the changes of $\left[\mathrm{Na}^{+}\right]_{\mathrm{i}}$ and $\left[\mathrm{K}^{+}\right]_{\mathrm{i}}$, the minimum $[\mathrm{glu}]_{\mathrm{o}}$ predicted at $\left[\mathrm{K}^{+}\right]_{\mathrm{o}}=60 \mathrm{~mm}$ is $60 \mu \mathrm{M}$.

These estimates are in the range known to trigger the death of neurons if maintained for a few minutes (Choi et al., 1987). Thus, even with the cotransport of three $\mathrm{Na}^{+}$, the glutamate transporters GLT-1 and EAAT3 will automatically raise $[\mathrm{glu}]_{\mathrm{o}}$ to neurotoxic levels in ischemia. 


\section{REFERENCES}

Amato A, Barbour B, Szatkowski M, Attwell D (1994a) Countertransport of potassium by the glutamate uptake carrier in glial cells isolated from the tiger salamander retina. J Physiol (Lond) 479:371-380.

Amato A, Ballerini L, Attwell D (1994b) Intracellular pH changes produced by glutamate uptake in rat hippocampal slices. J Neurophysiol 72:1686-1696.

Arriza JL, Eliasof S, Kavanaugh MP, Amara S (1977) Excitatory amino acid transporter 5, a retinal glutamate transporter coupled to a chloride conductance. Proc Natl Acad Sci USA 94:4155-4160.

Arriza JL, Fairman WA, Wadiche JI, Murdoch GH, Kavanaugh MP, Amara SG (1994) Functional comparisons of three glutamate transporter subtypes cloned from human motor cortex. J Neurosci 14:5559-5569.

Attwell D, Barbour B, Szatkowski M (1993) Nonvesicular release of neurotransmitter. Neuron 11:401-407.

Baetge EE, Bulloch K, Stallcup WB (1979) A comparison of glutamate uptake in cloned cell lines from the central nervous system. Brain Res 167:210-214.

Ballanyi K, Grafe P, ten Bruggencate G (1987) Ion activities and potassium uptake mechanisms of glial cells in guinea-pig olfactory cortex slices. J Physiol (Lond) 382:159-174.

Barbour B, Brew H, Attwell D (1988) Electrogenic glutamate uptake in glial cells is activated by intracellular potassium. Nature 335:433-435.

Bergles DE, Jahr CE (1997) Synaptic activation of glutamate transporters in hippocampal astrocytes. Neuron 19:1297-1308.

Billups B, Rossi D, Attwell D (1996) Anion conductance behavior of the glutamate uptake carrier in salamander retinal glial cells. J Neurosci 16:6722-6731.

Bouvier M, Szatkowski M, Amato A, Attwell D (1992) The glial cell glutamate uptake carrier countertransports $\mathrm{pH}$-changing anions. Nature 360:471-473.

Brew H, Attwell D (1987) Electrogenic glutamate uptake is a major current carrier in the membrane of axolotl retinal glial cells. Nature 327:707-709.

Choi DW, Maulucci-Gedde M, Kriegstein AR (1987) Glutamate neurotoxicity in cortical cell culture. J Neurosci 7:357-368.

Danbolt NC, Storm-Mathisen J, Kanner BI (1992) A $\left[\mathrm{Na}^{+}+\mathrm{K}^{+}\right]-$ coupled L-glutamate transporter purified from rat brain is located in glial cell processes. Neuroscience 51:295-310.

Eliasof S, Jahr S (1996) Retinal glial cell glutamate transporter is coupled to an anionic conductance. Proc Natl Acad Sci USA 93:4153-4158.

Erecinska M, Wantorsky D, Wilson DF (1983) Aspartate transport in synaptosomes from rat brain. J Biol Chem 258:9069-9077.

Fairman WA, Vandenberg RJ, Arriza JL, Kavanaugh MP, Amara SG (1995) An excitatory amino-acid transporter with properties of a ligand-gated chloride channel. Nature 375:599-603.

Friedman JE, Haddad GG (1994) Anoxia induces an increase in intracellular sodium in rat central neurons in vitro. Brain Res 663:329-334.

Gossen M, Freundlieb S, Bender G, Muller G, Hillen W, Bujard H (1995) Transcriptional activation by tetracyclines in mammalian cells. Science 268:1766-1769.

Haugeto $\varnothing$, Ullensvang K, Levy LM, Chaudhry FA, Honoré T, Nielsen M, Lehre KP, Danbolt NC (1996) Brain glutamate transporters form homomultimers. J Biol Chem 271:27715-27722.

Igo Jr RP, Ash JF (1996) New mutations and phenotypes associated with glutamate and aspartate transport in Chinese hamster ovary (CHO-K1) cells. Somat Cell Mol Genet 22:87-103.
Kanai Y, Nussberger S, Romero MF, Boron WF, Hebert SC, Hediger MA (1995) Electrogenic properties of the epithelial neuronal high affinity glutamate transporter. J Biol Chem 270:16561-16568.

Kanner BI, Sharon I (1978) Active transport of L-glutamate by membrane vesicles isolated from rat brain. Biochemistry 17:3949-3953.

Lehre KP, Levy LM, Ottersen OP, Storm-Mathisen J, Danbolt NC (1995) Differential expression of two glial glutamate transporters in the rat brain: quantitative and immunocytochemical observations. J Neurosci 15:1835-1853.

Levy LM, Attwell D, Hoover F, Ash JF, Bjørås M, Danbolt NC (1998) Inducible expression of the GLT-1 glutamate transporter in a $\mathrm{CHO}$ cell line selected for low endogenous glutamate uptake. FEBS Lett 422:339-342.

McBain CJ, Traynelis SF, Dingledine R (1990) Regional variation of extracellular space in the hippocampus. Science 249:674-677.

Nicholson C, Phillips JM (1981) Ion diffusion modified by tortuosity and volume fraction in the extracellular microenvironment of the rat cerebellum. J Physiol (Lond) 321:225-257.

Pines G, Danbolt NC, Bjørås M, Zhang Y, Bendahan A, Eide L, Koepsell H, Storm-Mathisen J, Seeberg E, Kanner BI (1992) Cloning and expression of a rat brain L-glutamate transporter. Nature 360:464-467.

Resnitzky D, Gossen M, Bujard H, Reed SI (1994) Acceleration of the $\mathrm{G}_{1} / \mathrm{S}$ phase-transition by expression of cyclin- $\mathrm{D}_{1}$ and cyclin- $\mathrm{E}$ with an inducible system. Mol Cell Biol 14:1669-1679.

Rink TJ, Tsien RY, Pozzan T (1982) Cytoplasmic $\mathrm{pH}$ and free $\mathrm{Mg}^{2+}$ in lymphocytes. J Cell Biol 95:189-196.

Siesjö BK (1990) Calcium excitotoxins and brain damage. News Physiol Sci 5:120-125.

Stallcup WB, Bulloch K, Baetge EE (1979) Coupled transport of glutamate and sodium in a cerebellar nerve cell line. J Neurochem 32:57-65.

Storm-Mathisen J, Danbolt NC, Rothe F, Torp R, Zhang N, Aas J-E, Kanner BI, Langmoen I, Ottersen OP (1992) Ultrastructural and immunocytochemical observations on the localization, metabolism, and transport of glutamate in normal and ischemic brain tissue. Prog Brain Res 94:225-241.

Szatkowski M, Attwell D (1994) Triggering and execution of neuronal death in brain ischaemia: two phases of glutamate release by different mechanisms. Trends Neurosci 17:359-365.

Szatkowski M, Barbour B, Attwell D (1990) Non-vesicular release of glutamate from glial cells by reversed electrogenic glutamate uptake. Nature 348:443-446.

Vandenberg RJ, Arriza JL, Amara SG, Kavanaugh MP (1995) Constitutive ion fluxes and substrate binding domains of human glial transporters. J Biol Chem 270:17668-17671.

Wadiche JI, Amara SG, Kavanaugh MP (1995a) Ion fluxes associated with excitatory amino acid transport. Neuron 15:721-728.

Wadiche JI, Arriza JL, Amara SG, Kavanaugh MP (1995b) Kinetics of a human glutamate transporter. Neuron 14:1019-1027.

Wang GJ, Chung HJ, Schnuer J, Pratt K, Zable AC, Kavanaugh MP, Rosenberg PA (1998) High affinity glutamate transport in rat cortical neurons in culture. Mol Pharmacol 53:88-96.

Zerangue N, Kavanaugh MP (1996a) Interaction of L-cysteine with a human excitatory amino acid transporter. J Physiol (Lond) 493:419-423.

Zerangue N, Kavanaugh MP (1996b) Flux coupling in a neuronal glutamate transporter. Nature 383:634-637. 